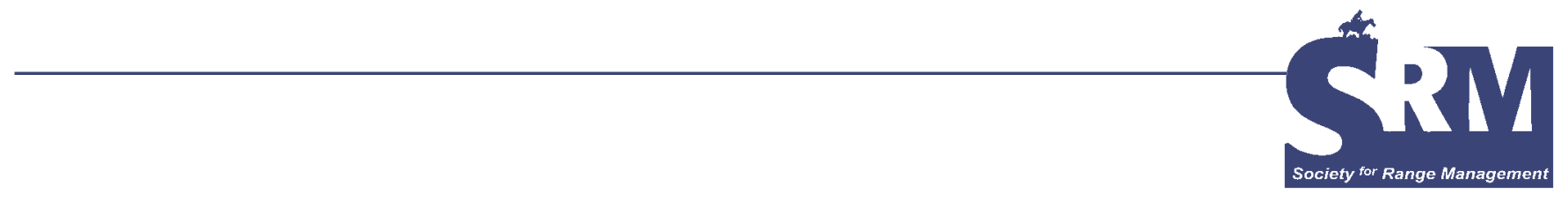

\title{
Grazing Impacts on Rangeland Vegetation: What We Have Learned
}

\section{Livestock Grazing at Light-to-Moderate Intensities Can \\ Have Positive Impacts on Rangeland Vegetation in Arid-to-Semiarid Areas.}

\section{By Jerry L. Holechek, Terrel T. Baker, Jon C. Boren, and Dee Galt}

\section{Introduction}

Conflict over livestock grazing in the western United States has increased as the land base in the West has shrunk due to rapid human population increase, urban sprawl, and lessened ties of much of the public to agricultural production. Antigrazing activists are making considerable use of the legal systems and media to further their cause. At the same time western ranchers have gained staunch supporters and stiffened their resolve to preserve their ranching heritage. It is our observation that both groups often present their cases more on the basis of emotion than sound scientific information. Impacts of managed livestock grazing compared with grazing exclusion on rangeland vegetation of the western United States have become better understood during the past 20 years as a result of more research and the publication of study results. However, most of this research is in highly technical, peer-reviewed journal articles that are generally not read by the public at large. We believe a careful analysis of the research on managed livestock grazing compared with grazing exclusion is needed to provide the public, ranchers, lawmakers, government planners, and conservationists with a sound basis for decision making. Semiarid and arid areas will receive emphasis because livestock grazing is most controversial on the public rangelands of the western United States. We will not attempt to exhaustively evaluate all the grazing studies in the western United States. Instead, we will
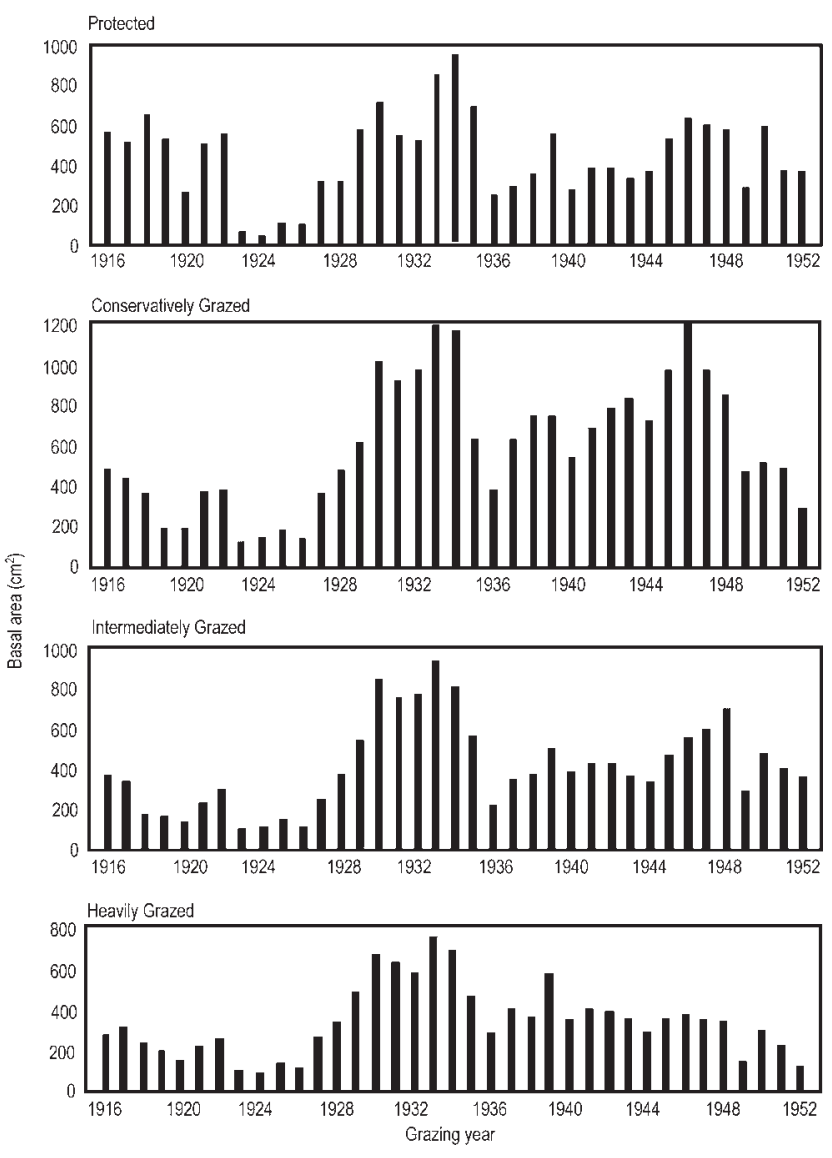

Figure 1. Basal area of black grama on meter-square quadrats protected from grazing and at 3 intensities of grazing on the Jornada Experimental Range, southern New Mexico, 1916-1953 (from Paulsen and $\operatorname{Ares}^{2}$ ). 
Table 1. Description of grazing intensity categories

\begin{tabular}{|c|c|c|}
\hline $\begin{array}{l}\text { Qualitative grazing } \\
\text { intensity category }\end{array}$ & $\begin{array}{l}\text { Use of forage by } \\
\text { weight }(\%)\end{array}$ & Qualitative indicators of grazing intensity \\
\hline Light to nonuse & $0-30$ & $\begin{array}{l}\text { Only choice plants and areas show use. There is no use of poor } \\
\text { forage plants. }\end{array}$ \\
\hline Conservative & $31-40$ & $\begin{array}{l}\text { Choice forage plants have abundant seed stalks. Areas more than } 1 \\
\text { mile from water show little use. About one-third to one-half primary } \\
\text { forage plants show grazing on key areas. }\end{array}$ \\
\hline Moderate & $41-50$ & $\begin{array}{l}\text { Most of accessible range show use. Key areas show patchy appear- } \\
\text { ance with one-half to two-thirds of primary forage plants showing use. } \\
\text { Grazing is noticeable in zone } 1-1.5 \text { miles from water. }\end{array}$ \\
\hline Heavy & $51-60$ & $\begin{array}{l}\text { Nearly all primary forage plants show grazing on key areas. Palatable } \\
\text { shrubs show hedging. Key areas show a lack of seed stalks. Grazing is } \\
\text { noticeable in areas over } 1.5 \text { miles from water. }\end{array}$ \\
\hline Severe & $61+$ & $\begin{array}{l}\text { Key areas show a clipped or mowed appearance (no stubble height). } \\
\text { Shrubs are severely hedged. There is evidence of live stock trailing to } \\
\text { forage. Areas over } 1.5 \text { miles from water lack stubble height. }\end{array}$ \\
\hline
\end{tabular}

Source: Based on Holechek et al. ${ }^{1}$

closely examine those that have compared carefully controlled intensity, timing, and frequency of grazing with grazing exclusion. The reader is referred to Holechek et al. ${ }^{1}$ for a detailed review of various studies comparing grazing outcomes under different stocking rates and rotation systems.

\section{Vegetation Trends}

In western North America, we found 20 studies with some degree of replication in time and space that compare vegetation responses of grazing at moderate-to-light intensities with grazing exclusion. A description of the different cate-

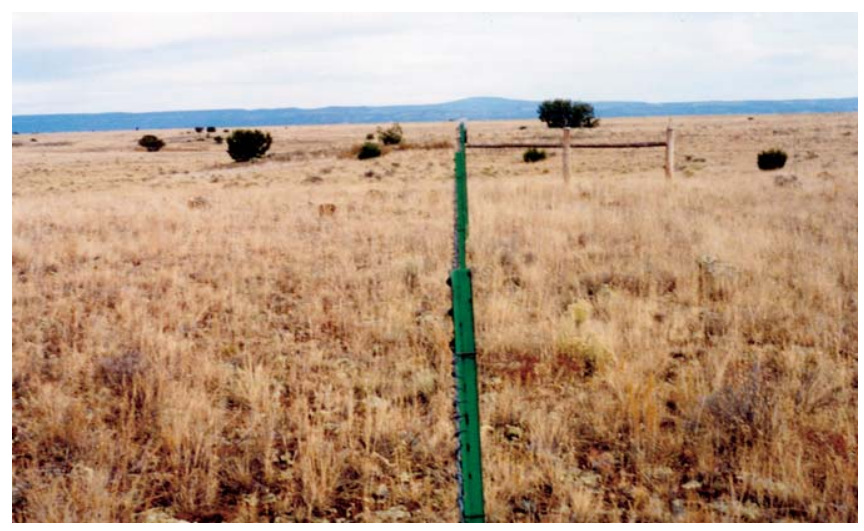

Figure 2. After 5 years of below-average precipitation, perennial grass production and vegetation composition were the same under conservative grazing (left) and 21 years of grazing exclusion (right). Vegetation composition was the same both outside and inside the exclosure. This photo was taken in early November 2003 on short-grass rangeland in west-central New Mexico. gories of grazing intensity is provided in Table 1 . These studies are summarized in Table 2. Sixteen of these studies evaluated trend, 11 evaluated productivity, and 2 evaluated drought responses on lands under managed grazing compared with grazing exclusion. Only 7 of the studies involve arid rangelands. Studies that did not provide some type of quantitative or qualitative characterization of grazing intensity, timing, and frequency were excluded from our review.

Fourteen of the 18 studies evaluating trends had sufficient baseline information so that vegetation changes through time could be determined. In all 14 of the studies, ungrazed and moderately-to-lightly grazed treatments showed the same trend. Ten studies showed an upward trend, 2 showed a downward trend, and 2 showed no definite trend. Paulsen and $\mathrm{Ares}^{2}$ reported a downward trend on Chihuahuan Desert rangeland due to drought, and Skovlin et al. ${ }^{3}$ associated a downward trend on coniferous forest rangeland with increasing tree cover. In 6 of the 18 studies, plant community composition did not differ between grazed and ungrazed areas. Grazed areas were considered to be in higher ecological condition (more climax vegetation) in 5 studies and lower in 5 studies when compared with ungrazed controls. Two studies $^{2,4}$ merit special consideration because they involved long time periods (more than 20 years), were well replicated in space, and provided detailed characterization of grazing intensity. In both studies, grazing was found to be sustainable at intensities that involved up to $40 \%$ use of forage.

On the Colorado short-grass prairie, prickly pear cactus biomass was lowered by 56 years of moderate grazing ( $40 \%$ use) compared to exclusion. ${ }^{4}$ Shrub biomass (mostly fringed 
Table 2. Studies comparing vegetation responses of controlled grazing at moderate-to-light intensities with grazing exclusion

\begin{tabular}{|c|c|c|c|c|}
\hline Range type & Location & $\begin{array}{l}\text { Vegetation respons- } \\
\text { es studied }\end{array}$ & Grazing treatment & Reference \\
\hline Northern mixed prairie & Alberta, Canada & Production & $\begin{array}{l}\text { Light grazing, grazing } \\
\text { exclusion }\end{array}$ & Johnston ${ }^{17}$ \\
\hline Northern mixed prairie & North Dakota & Trend & $\begin{array}{l}\text { Moderate grazing, graz- } \\
\text { ing exclusion }\end{array}$ & Brand and Goetz ${ }^{18}$ \\
\hline Northern mixed prairie & Alberta, Canada & Trend & $\begin{array}{l}\text { Grazing intensities, graz- } \\
\text { ing exclusion }\end{array}$ & Smoliak et al..$^{19}$ \\
\hline Northern mixed prairie & Montana & Trend & $\begin{array}{l}\text { Conservative stocking, } \\
\text { grazing exclusion }\end{array}$ & Vogel and Van Dyne 20 \\
\hline Southern mixed prairie & Texas & Productivity, trend & $\begin{array}{l}\text { Stocking rates, grazing } \\
\text { systems, grazing exclusion }\end{array}$ & Wood and Blackburn ${ }^{21}$ \\
\hline Southern mixed prairie & Texas & Trend & $\begin{array}{l}\text { Stocking rates, grazing } \\
\text { systems, grazing exclusion }\end{array}$ & Thurow et al. ${ }^{22}$ \\
\hline Southern mixed prairie & Texas & Productivity, trend & $\begin{array}{l}\text { Stocking rates, grazing } \\
\text { exclusion }\end{array}$ & Heitschmidt et al. ${ }^{23}$ \\
\hline Southern mixed prairie & Texas & Productivity, trend & $\begin{array}{l}\text { Stocking rates, grazing } \\
\text { systems, grazing exclusion }\end{array}$ & Reardon and Merrill ${ }^{10}$ \\
\hline Short-grass prairie & Colorado & Productivity & $\begin{array}{l}\text { Stocking rates, grazing } \\
\text { exclusion }\end{array}$ & Milchunas et al. ${ }^{24}$ \\
\hline Short-grass prairie & Colorado & Trend & $\begin{array}{l}\text { Stocking rates, grazing } \\
\text { exclusion }\end{array}$ & Hart and Ashby ${ }^{4}$ \\
\hline Coniferous forest & Colorado & $\begin{array}{l}\text { Productivity, drought } \\
\text { response trend }\end{array}$ & $\begin{array}{l}\text { Stocking rates, grazing } \\
\text { exclusion }\end{array}$ & Johnson, ${ }^{13,25}$ Smith $^{26}$ \\
\hline Coniferous forest & Oregon & Productivity, trend & $\begin{array}{l}\text { Stocking rates, grazing } \\
\text { systems, grazing exclusion }\end{array}$ & Skovlin et al..$^{3}$ \\
\hline Palouse bunchgrass & Oregon & Productivity, trend & $\begin{array}{l}\text { Stocking rates, grazing } \\
\text { systems, grazing exclusion }\end{array}$ & Skovlin et al. ${ }^{3}$ \\
\hline Sagebrush grassland & New Mexico & Trend & $\begin{array}{l}\text { Moderate stocking, graz- } \\
\text { ing exclusion }\end{array}$ & $\begin{array}{l}\text { Holechek and } \\
\text { Stephenson }{ }^{27}\end{array}$ \\
\hline Sagebrush grassland & Idaho & Trend & $\begin{array}{l}\text { Timed grazing, grazing } \\
\text { exclusion }\end{array}$ & Bork et al. ${ }^{28}$ \\
\hline Sagebrush grassland & Oregon & Drought response & $\begin{array}{l}\text { Grazing intensity, grazing } \\
\text { exclusion }\end{array}$ & Ganshopp and Bedell ${ }^{12}$ \\
\hline Chihuahuan Desert & New Mexico & Trend, drought response & $\begin{array}{l}\text { Grazing intensities, graz- } \\
\text { ing exclusion }\end{array}$ & Paulsen and Ares $^{2}$ \\
\hline Chihuahuan Desert & New Mexico & Productivity, trend & $\begin{array}{l}\text { Conservative grazing, } \\
\text { grazing exclusion }\end{array}$ & Herbel and Gibbens ${ }^{5}$ \\
\hline Salt Desert & Utah & Trend & $\begin{array}{l}\text { Grazing timing, grazing } \\
\text { exclusion }\end{array}$ & Alzerreca-Angelo et al. ${ }^{29}$ \\
\hline Mojave Desert & Utah/Arizona & Trend & $\begin{array}{l}\text { Grazing intensity, grazing } \\
\text { exclusion }\end{array}$ & Jeffries and Klopatek ${ }^{30}$ \\
\hline
\end{tabular}




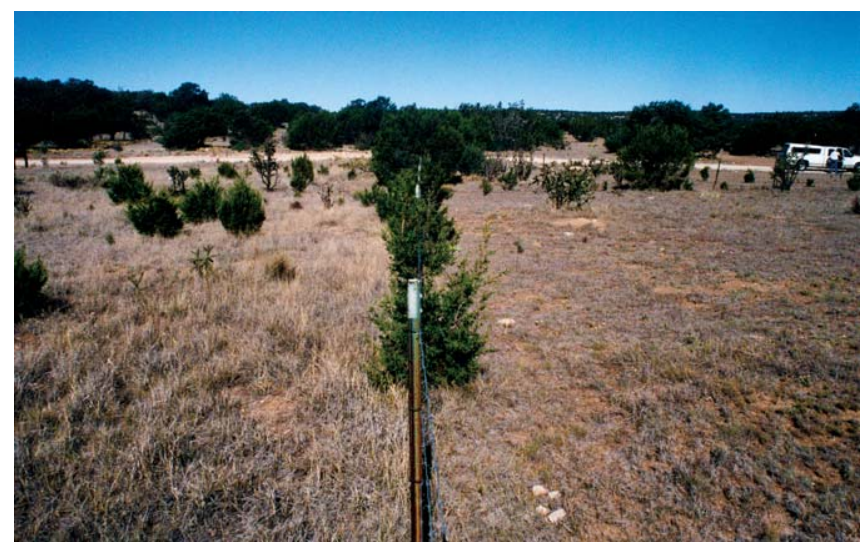

Figure 3. Both perennial grass production and plant survival were higher under light grazing (left) than under long-term grazing exclusion on this pinyon-juniper rangeland in southeastern New Mexico (photo taken in May 2002).

sagewort, slender eriogonum, and broom snakeweed) was higher under exclusion than under grazing. The lower cactus and shrub component under grazing treatments was considered advantageous because those plants are associated with retrogression away from the climax plant community and have low forage value for livestock and wildlife. Light and moderate grazing reduced cool-season graminoids but increased warm-season graminoids (grasses) compared with exclusion. Forb biomass did not differ among grazed and ungrazed treatments. It was concluded that moderate cattle grazing had been sustainable during the 55-year period of study.

In the Chihuahuan Desert of New Mexico, black grama basal cover, over a 37-year period, was maintained at a higher level under conservative grazing (35\% use) than under either grazing exclusion or heavier grazing levels ${ }^{2}$ (Fig. 1). Black grama is the primary decreaser forage grass (grass that diminishes under heavy grazing) in the Chihuahuan Desert and dominates rangelands in climax condition. Findings from the Paulsen and $\mathrm{Ares}^{2}$ study are supported by additional follow-up research from the same study areas by Herbel and Gibbens. ${ }^{5}$ In contrast tobosa, a perennial increaser grass that grows on bottomland sites, was better maintained under moderate grazing than under conservative grazing, heavy grazing, or protection (Table 3). Tobosa actually had lower basal area under protection than heavy grazing.

Further evidence that managed grazing is sustainable in arid environments is provided by Navarro et al. ${ }^{6}$ This study evaluated long-term (1952-1999) trends in ecological condition on 41 grazed sites, well-scattered across Bureau of Land Management rangelands in the Chihuahuan Desert of southern New Mexico. Over the 48-year study period, major changes occurred in rangeland condition due to fluctuation in precipitation. However, at the end of the study, average ecological condition score across sites was the same as at the beginning. The average percentage of cover by primary forage grasses was the same. The authors concluded that managed livestock grazing is sustainable on Chihuahuan Desert rangelands.

\section{Plant Diversity}

Very few studies have evaluated the effects of managed grazing on plant diversity in arid and semiarid areas. In the Chihuahuan Desert of south-central New Mexico, Smith et al. ${ }^{7}$ reported vegetation diversity was higher on long-term, conservatively grazed, late-seral rangeland than on lightly grazed rangeland in near-climax condition. In another study in the same area, Nelson et al. ${ }^{8}$ reported vegetation diversity was the same on moderately grazed, mid-seral, and conservatively grazed, late-seral rangelands. On the short-grass prairie of Colorado, Milchunas et al. ${ }^{9}$ found plant diversity increased as grazing intensity decreased. However, the difference in plant diversity between ungrazed and lightly grazed areas was small.

\section{Vegetation Productivity}

Long-term managed grazing compared with grazing exclusion, on average, reduced grass production $13 \%$ and total vegetation production 4\% across 11 different studies (Table 4). The Chihuahuan Desert study by Herbel and Gibbens ${ }^{5}$ merits particular consideration because it involved 2 sites and 19 years of data collection. Grazing intensities were conservative (30\%-35\% average use of forage). On both sites in this study, managed grazing resulted in slightly higher grass production than exclusion. In arid areas, it appears that grazing at conservative levels may have no effect or a stimulative effect on forage production. This, however, needs to be better studied.

Two studies provide evidence that long-term grazing exclusion can result in vegetation stagnation. On chaparral rangeland in south-central Texas, Reardon and Merrill ${ }^{10}$ found production of decreaser grasses was lower under grazing exclusion than under a moderately stocked, 4-pasture, deferred-rotation grazing system. On desert shrub rangelands in Nevada, Tueller and Tower ${ }^{11}$ found productivity of desirable shrubs (bitterbrush) was lower but productivity of grass-

\begin{tabular}{|c|c|c|}
\hline $\begin{array}{l}\text { Grazing } \\
\text { intensity }\end{array}$ & $\begin{array}{l}\text { Use of } \\
\text { forage }(\%)\end{array}$ & $\begin{array}{l}\text { Average basal } \\
\text { area of tobosa } \\
\left(\text { inches }^{2} / \text { yards }^{2} \text { ) }\right.\end{array}$ \\
\hline Protected & 0 & 157 \\
\hline Conservative & $<40$ & 324 \\
\hline $\begin{array}{l}\text { Intermediate } \\
\text { (moderate) }\end{array}$ & $40-55$ & 358 \\
\hline Heavy & $>55$ & 302 \\
\hline
\end{tabular}


Table 4. Summary of studies evaluating vegetation productivity under controlled grazing and grazing exclusion in North America

\begin{tabular}{|c|c|c|c|c|c|c|c|c|}
\hline \multirow[b]{2}{*}{ Reference } & \multirow[b]{2}{*}{ Location } & \multirow[b]{2}{*}{ Range Type } & \multicolumn{3}{|c|}{ Grass productivity (Ibs/acre) } & \multicolumn{3}{|c|}{$\begin{array}{l}\text { Total vegetation productivity } \\
\text { (Ibs/acre) }\end{array}$} \\
\hline & & & Grazed & Excluded & $\begin{array}{l}\text { Difference } \\
\quad(\%)\end{array}$ & Grazed & Excluded & $\begin{array}{l}\text { Difference } \\
\quad(\%)\end{array}$ \\
\hline Johnston ${ }^{17}$ & $\begin{array}{l}\text { Alberta, } \\
\text { Canada }\end{array}$ & $\begin{array}{l}\text { Northern } \\
\text { mixed prairie }\end{array}$ & 1,237 & 1,446 & -14 & 2,162 & 2,199 & -2 \\
\hline $\begin{array}{l}\text { Brand and } \\
\text { Goetz }^{18}\end{array}$ & $\begin{array}{l}\text { North } \\
\text { Dakota }\end{array}$ & $\begin{array}{l}\text { Northern } \\
\text { mixed prairie }\end{array}$ & 1,371 & 1,584 & -13 & 1,562 & 1,698 & -8 \\
\hline $\begin{array}{l}\text { Vogel and } \\
\text { Van Dyne }\end{array}$ & Montana & $\begin{array}{l}\text { Northern } \\
\text { mixed prairie }\end{array}$ & 425 & 465 & -9 & 583 & 652 & -11 \\
\hline $\begin{array}{l}\text { Wood and } \\
\text { Blackburn }{ }^{21}\end{array}$ & Texas & $\begin{array}{l}\text { Southern } \\
\text { mixed prairie }\end{array}$ & 2,920 & 3,740 & -22 & - & - & - \\
\hline $\begin{array}{l}\text { Heitschmidt } \\
\text { et al..23 }\end{array}$ & Texas & $\begin{array}{l}\text { Southern } \\
\text { mixed prairie }\end{array}$ & 1,025 & 1,273 & -19 & 1,042 & 1,282 & -19 \\
\hline $\begin{array}{l}\text { Reardon and } \\
\text { Merrill }\end{array}$ & Texas & $\begin{array}{l}\text { Southern } \\
\text { mixed prairie }\end{array}$ & 1,078 & 903 & +14 & 2,159 & 1,404 & +54 \\
\hline $\begin{array}{l}\text { Milchunas et } \\
\text { al. }{ }^{24}\end{array}$ & Colorado & Short-grass & 632 & 668 & -5 & - & - & - \\
\hline Johnson ${ }^{25}$ & Colorado & $\begin{array}{l}\text { Coniferous for- } \\
\text { est }\end{array}$ & 652 & 1,094 & -40 & 874 & 1,457 & -40 \\
\hline $\begin{array}{l}\text { Skovlin et } \\
\text { al. }{ }^{3}\end{array}$ & Oregon & $\begin{array}{l}\text { Coniferous for- } \\
\text { est }\end{array}$ & 90 & 142 & -37 & 249 & 300 & -17 \\
\hline $\begin{array}{l}\text { Skovlin et } \\
\text { al. }^{3}\end{array}$ & Oregon & Palouse prairie & 156 & 182 & -14 & 333 & 312 & +7 \\
\hline $\begin{array}{l}\text { Herbel and } \\
\text { Gibbens }\end{array}$ & New Mexico & $\begin{array}{l}\text { Chihuahuan } \\
\text { desert }\end{array}$ & 191 & 183 & +4 & - & - & - \\
\hline Average & & & 889 & 1,062 & -13 & 1,112 & 1,152 & -4 \\
\hline
\end{tabular}

es was higher on grazing excluded compared with grazed areas. This study was not included in Table 3 because quantitative information on grazing intensity was not reported.

Most of the productivity studies in Table 4 apparently did not use cages on grazed areas to calculate herbage removed by livestock. Another problem that we encountered in reviewing the studies is that many of them did not clearly state whether old growth was separated from new growth. In the Herbel and Gibbens ${ }^{5}$ study, in which grass production was slightly higher on grazed areas, the authors do state that their estimates involved only current-year growth.

\section{Drought Response}

Three studies indicate that light-to-conservative grazing may actually benefit grass plants during drought compared with no grazing., ${ }^{2,12,13}$ In eastern Oregon, lightly grazed Idaho fescue and bluebunch wheatgrass had as much and, in some cases, more herbage, seed stalks, and final height than ungrazed plants following severe drought. ${ }^{12}$ Similar observations were made for black grama on Chihuahuan Desert rangeland in New Mexico. ${ }^{2}$ On coniferous forest rangeland in Colorado, Johnson ${ }^{13}$ found moderately and lightly grazed pastures had less reduction in forage production than ungrazed plots during drought. 


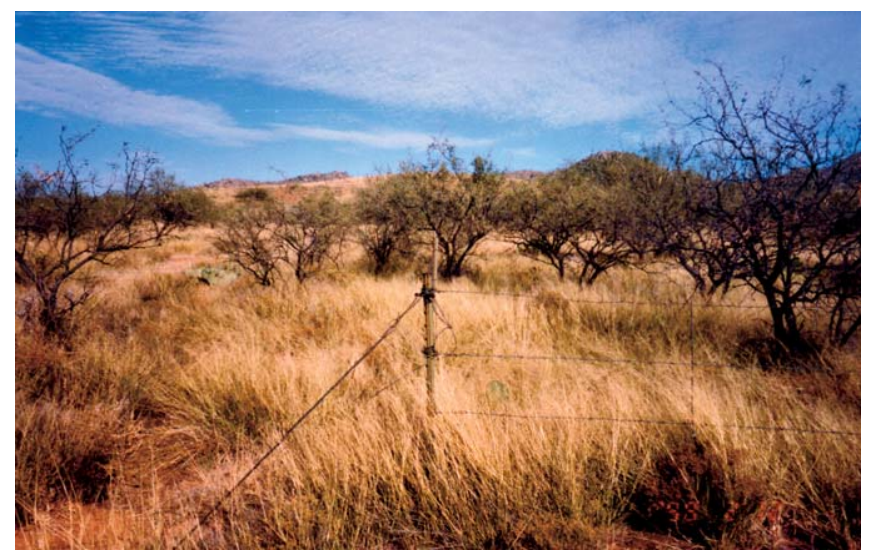

Figure 4. Forage production has been similar under conservative grazing (left) and long-term grazing exclusion (right) on this ranch in southeastern Arizona. However, native perennial grasses were more prevalent outside the exclosure compared with inside the exclosure where the exotic perennial grass, Lehmann lovegrass, predominated (photo taken in November 2003).

\section{Positive Influences of Managed Grazing}

Possible positive influences of managed grazing compared with grazing exclusion on range plant productivity are reviewed by Holechek ${ }^{14}$ and Holechek et al. ${ }^{1}$ These influences include removal of excess vegetation that may negatively affect net carbohydrate fixation, maintaining an optimal leaf area index, reducing transpiration losses, reducing excess accumulations of standing dead vegetation and mulch, increased tillering in grasses, and reducing apical dominance in shrubs, as well as inoculating plant parts with saliva, which may stimulate growth. Nearly all of the studies identifying these responses were conducted in greenhouses rather than under range conditions. Research by McNaughton ${ }^{15}$ in the African Serengeti provides one of the best validations that grazing does have positive or compensating effects on forage plant productivity, whereas Belsky ${ }^{16}$ reviews contradictory evidence.

During the past 10 years, we have had the opportunity to evaluate rangeland vegetation responses on several lightly-toconservatively grazed ranges compared with grazing-excluded sites distributed across New Mexico and Arizona. During this period, severe drought has prevailed. Forage plant survival and productivity have generally been higher on the grazed land compared with grazing-excluded sites (Figs. 2-4). However, the differences were often of small magnitude.

Our conclusion is that, in arid and semiarid areas, grazing can have positive impacts on forage plants compared with exclusion if average long-term use levels do not exceed $40 \%$. However, we acknowledge research supporting this viewpoint is limited. A major challenge for rangeland researchers in the 21 st Century will be to provide better information on this subject.

Authors are Professor of Range Science, Department of Animal and Range Sciences, New Mexico State University, Las Cruces, NM
88003, holechek@nmsu.edu (Holechek); Extension Specialists, Extension Animal Resources, New Mexico State University, Las Cruces, NM 88003 (Baker, Boren); and Private Range Consultant, 3000 Devandale Drive, Las Cruces, NM 88005 (Galt). This paper was supported by the New Mexico Agricultural Experiment Station and was part of project 1-5-274170.

\section{References}

1. Holechek, J. L., R. D. Pieper, And C. H. Herbel. 2004. Range management: Principles and practices. 5th ed. Upper Saddle River, NJ: Prentice-Hall.

2. Paulsen, H. A., AND F. N. Ares. 1962. Grazing values and management of black grama and tobosa grasslands and associated shrub ranges of the southwest. Washington, DC: US Department of Agriculture. Technical Bulletin 1270.

3. Skovlin, J. M., R. W. Harris, G. S. Strickler, and G. A. GARRISON. 1976. Effects of cattle grazing methods on ponderosa pine-bunchgrass range in the Pacific Northwest. Washington, DC: US Department of Agriculture. Technical Bulletin 1531.

4. HART, R. H., AND M. M. Ashby. 1998. Grazing intensities, vegetation, and heifer gains: 55 years on short-grass. Journal of Range Management 51:392-398.

5. Herbel, C. H., AND R. P. Gibbens. 1996. Post-drought vegetation dynamics on arid rangelands of New Mexico. Las Cruces, NM: New Mexico Agricultural Experiment Station. Bulletin 776.

6. Navarro, J., D. Galt, J. HolecheK, J. McCormick, and F. Molinar. 2002. Long-term impacts of livestock grazing on Chihuahuan Desert rangelands. Journal of Range Management 55:400-405.

7. Smith, G., J. L. HolecheK, and M. Cardenas. 1996. Wildlife numbers on excellent and good condition Chihuahuan Desert rangelands: an observation. Journal of Range Management 49:489-493.

8. Nelson, T., J. L. HolecheK, R. Valdez, and M. Cardenas. 1997. Wildlife numbers on late and mid-seral Chihuahuan Desert rangelands. Journal of Range Management 50:593-599.

9. Milchunas, D. G., O. E. Sala, and W. K. Lauenroth. 1988. A generalized model of the effects of grazing by large herbivores on grassland community structure. American Naturalist 132:87-106.

10. Reardon, P. O., And L. B. Merrill. 1976. Vegetation response under various grazing management systems in the Edward Plateau of Texas. Journal of Range Management 29:195-198.

11. Tueller, P. T., AND J. D. Tower. 1979. Vegetation stagnation in three-phase big game exclosures. Journal of Range Management 32:258-263.

12. Ganskopp, D. C., AND T. Bedell. 1981. An assessment of vigor and production of range grasses following drought. Journal of Range Management 34:137-141.

13. Johnson, W. M. 1956. The effect of grazing intensity on plant composition, vigor, and growth of pine-bunchgrass ranges in central Colorado. Ecology 37:790-798. 
14. HolecheK, J. L. 1981. Livestock grazing impacts on public lands: a viewpoint. Journal of Range Management 34:251-254.

15. McNaughton, S. J. 1983. Compensatory plant growth as a response to herbivory. Oikos 40:329-336.

16. Belsky, A. J. 1986. Does herbivory benefit plants? a review of the evidence. American Naturalist 127:870-892.

17. Johnson, A. 1962. Comparison of lightly grazed and ungrazed range in the fescue grassland of southwestern Alberta. Canadian Journal of Plant Science 41:614-622.

18. BRAND, M. D., AND H. GoETZ. 1986. Vegetation of exclosures in southwestern North Dakota. Journal of Range Management 39:434-438.

19. Smoliak, S., J. F. DormaAr, And A. Johnston. 1972. Longterm grazing effects on Stipa-Boute-Coua prairie soils. Journal of Range Management 25:246-249.

20. Vogel, W., And G. M. VAn Dyne. 1966. Vegetation responses to grazing management on a foothill sheep range. Journal of Range Management 19:80-85.

21. WoOd, M. K., And W. H. BlackBuRn. 1984. Vegetation and soil responses to cattle grazing systems in the Texas Rolling Plains. Journal of Range Management 37:298-303.

22. Thurow, T. L., W. H. Blackburn, and C. A. TaYlor, JR. 1986. Hydrologic characteristics of vegetation types as affected by livestock grazing systems. Edwards Plateau, Texas. Journal of Range Management 39:505-508.

23. Heitschmidt, R. K., S. L. Dowhower, R. A. Gordon, And D. L. PRICE. 1985. Response of vegetation to livestock grazing at the Texas Experimental Ranch. College Station, TX: Texas
A\&M University Agricultural Experimental Station. Bulletin 1515.

24. Milchunas, D. G., J. R. Forwood, and W. K. Lauenroth. 1994. Productivity of long-term grazing treatments in response to seasonal precipitation. Journal of Range Management 47:133-139.

25. Johnson, W. M. 1953. Effect of grazing intensity upon vegetation and cattle gains on ponderosa pine-bunchgrass ranges of the front range of Colorado. Washington, DC: US Department of Agriculture. Circular 929.

26. SMITH. D. R. 1967. Effects of cattle grazing on a ponderosa pine-bunchgrass range in Colorado. Washington, DC: US Department of Agriculture, Forest Service. Technical Bulletin 1371.

27. Holechek, J. L., And T. Stephenson. 1983. Comparison of big sagebrush vegetation in north central New Mexico under moderately grazed and grazing excluded condition. Journal of Range Management 36:455-457.

28. Bork, E. W., N. B. West, And J. W. Walker. 1998. Cover components on long-term seasonal sheep grazing treatments in three-tip sagebrush steppe. Journal of Range Management 51:293-301.

29. Alzerreca-Angelo, H., E. W. Schupp, and S. G. Kitchen. 1998. Sheep grazing and plant cover dynamics of a shadscale community. Journal of Range Management 51:214-223.

30. JefFries, D. L., AND J. M. KLOPATEK. 1987. Effects of grazing on the vegetation of the blackbrush association. Journal of Range Management 40:390-393. 